\title{
Exploring Indian Spices As Promising Antimicrobial Agents
}

Kirti Garg ( $\square$ garg.kirti1@gmail.com )

Amity University Amity Institute of Biotechnology

Astha Giri

University of Delhi

\section{Research}

Keywords: antimicrobial activity, spices, phytochemicals, agar dilution, disk diffusion, Minimum inhibitory concentration, Zone of Inhibition, food borne pathogens

Posted Date: November 18th, 2020

DOl: https://doi.org/10.21203/rs.3.rs-109624/v1

License: (c) (i) This work is licensed under a Creative Commons Attribution 4.0 International License. Read Full License 


\section{Abstract}

Background: Infectious diseases caused by pathogens, and food contamination caused by microorganisms, are compromising human health. The efficacies of antimicrobials have weakened by microbial resistance, while antibiotic toxicity is another challenge, arising the need of natural antimicrobial agents.

Objective: Spices have been long used to enhance flavor and aroma of food, and for their antimicrobial and antioxidant activities. In this study, antimicrobial activity of aqueous and ethanolic extracts of five Indian spices i.e. Black pepper, Carom, Cinnamon, Clove and Cumin, was explored against Escherichia coli and Staphylococcus aureus, by agar dilution method and disk diffusion method.

Methods: For agar dilution, aqueous and ethanolic extracts, with concentrations ranging from $0.5 \mathrm{mg} / \mathrm{ml}-8 \mathrm{mg} / \mathrm{ml}$, were used. For disc diffusion method, varying concentrations of the ethanolic extracts $(50 \%, 75 \%$ and $100 \%)$ were used.

Results: The results showed inhibitory effect on the growth of the microbes at higher concentrations of extracts. Clove's bud showed the best antimicrobial effect, having minimum inhibitory concentration (MIC) less than $0.5 \mathrm{mg} / \mathrm{ml}$ for aqueous extract and $6 \mathrm{mg} / \mathrm{ml}$ for ethanolic extract against both bacteria, and had the biggest zone of inhibition i.e. $21 \mathrm{~mm}$, against E. coli, while Black pepper had a zone of inhibition of $20 \mathrm{~mm}$ against $S$. aureus.

Conclusion: It was noted that the spice extracts, in general, were more effective against $S$. aureus than E. coli. Therefore, spices and particularly Clove and Black pepper extracts have great potential to be further tested and developed as novel safe antimicrobial agents.

\section{Background}

Microbial diseases are proving to be the serious health issue throughout the world these days. The use of antibiotics has revolutionized the treatment of various bacterial infections. However, their indiscriminate use has led to an alarming increase in antibiotic resistance, among microorganisms, considered as one of the greatest threats to human health today. ${ }^{1}$ This has necessitated the need for development of novel antimicrobials. Many evidences suggest that consumption of fruit and vegetables is beneficial for human health and may help in the prevention of chronic diseases. ${ }^{2}$ Traditional healers have long been using plants to treat a wide range of diseases, but these methods of treatment are still not accepted in many parts of the world. Plants contain secondary metabolites like tannins, terpenoids, alkaloids and flavonoids. These are called phytochemicals. ${ }^{3}$ Phytochemicals are originally meant to act as the plant defense mechanism but other than this they also exert potent antimicrobial properties against sensitive and pathogenic bacteria. Likewise, some natural substances have effective antimicrobial properties where they have been used as seasonings for centuries. ${ }^{4}$ Spices and aromatic vegetable materials have long been used in food not only for their flavor and fragrance qualities but also for their preservative and medicinal properties, for instance, carom seeds have been commonly used to treat gastrointestinal disorders while clove is used for toothache due to its local anesthetic activity. Since the ancient times, they have been used for preventing food spoilage and deterioration and for extending the shelf life of food. In addition, they show other beneficial biological properties, such as antimicrobial and antioxidant activities. ${ }^{5}$ Although, the antimicrobial properties of spices may differ depending on the form of spices added, such as fresh, dried, or extracted forms and might also differ depending on the harvesting seasons and between geographical sources. ${ }^{6}$ Over the time, with the usage of spices, it has been hypothesized that they exert antimicrobial properties but there is no core evidence of which spice is most promising and to what extent. ${ }^{7}$ In the present study, we have evaluated the antimicrobial activity of the extracts of five widely used spices in India, Syzygium aromaticum (Clove), Cuminum cyminum (Cumin), Cinnamomum verum (Cinnamon), Trachyspermum ammi (Carom seeds) and Piper nigrum (Black pepper) against bacterial food borne pathogens such as Esterichia coli and Staphylococcus aureus, using two methods i.e. Agar dilution and Disk diffusion method, the results are discussed.

\section{Material And Methods}

\section{Media used}

nutrient agar, LB broth

\section{Extracts}

spices were collected from the market. Sample was grinded, by mortar and pestle, and sieved to obtain fine powder. Names of the Indian spices used in the study are mentioned in Table 1, along with their few details. Lowering the particle size increases surface contact between samples and extraction solvents. So, smaller the particle size, better it will soak into the solvent. ${ }^{8}$

Table 1

Names of all the spices chosen for the study with their scientific name, name of the family, English name, common name and the plant part which is used in the research

\begin{tabular}{|lllll|}
\hline SCIENTIFIC NAME & FAMILY NAME & ENGLISH NAME & COMMON NAME & PLANT PART USED \\
\hline Piper nigrum & Piperaceae & Black pepper & Kali mirch & Seeds \\
\hline Trachyspermum ammi & Umbellifers & Carom & Ajwain & Seeds \\
\hline Cinnamon verum & Laurels & Cinnamon & Dalchini & Bark \\
Syzygium aromaticum & Myrtle & Clove & Laung & Bud \\
\hline Cuminum cyminum & Umbellifers & Cumin & Jeera & Seeds \\
\hline
\end{tabular}


Extracts of these five spices were prepared by soaking a small amount of sample in the selected solvent overnight and later filtered with the help of Whatman paper.

Since fresh samples are fragile and tend to deteriorate faster, dried samples of spices are taken. ${ }^{8}$

\section{Preparation of extracts:}

Aqueous extract- $2 \mathrm{~g}$ of finely powdered sample added to $20 \mathrm{ml}$ sterilized distilled water (10\% concentration) and left overnight.

Ethanol extract- $2 \mathrm{~g}$ of finely powdered sample added to $10 \mathrm{ml}$ ethanol ( $20 \%$ concentration) and left overnight.

Figure 1 shows all the spice extracts prepared. First, these mixtures were filtered with the help of funnel and Whatman paper and then using micron-filters, to remove all the residue. After measuring the volumes of the extracts obtained, they are stored in respective glass bottles. ${ }^{8}$

\section{Bacterial Strains used:}

Two very common food borne pathogens were used to test the antimicrobial effect of spices, a) Staphylococcus aureus and b) Esterichia coli. The effect of spices was also tested on the environmental microbes.

E. coli is an enteric gram-negative, multitalented Bacillus. E. coli assuredly breeds in humans and in animal gut lumen in mass culture.

Staphylococcus aureus is a Gram-positive, round-shaped bacterium that is a member of the Firmicutes, and it is a usual member of the microbiota of the body, frequently found in the upper respiratory tract and on the skin. ${ }^{9}$

\section{ANTIMICROBIAL ACTIVITY OF SPICES}

\section{Agar dilution method}

\section{Preparation of plates:}

For aqueous extracts

7 plates for each spice sample are prepared, by agar dilution method.

A mixture of diluted extract (of concentrations $0.5,1,2,4,8 \mathrm{mg} / \mathrm{ml}$ ) and nutrient agar was poured in 5 plates while one was negative, with antibiotic kanamycin, and one was positive, with no extract and only nutrient medium.

For ethanolic extracts

with the same method, plates of different spices are prepared under different dilutions or concentrations.

Concentrations for cumin and cinnamon extracts: $0.5,1,2,4,8 \mathrm{mg} / \mathrm{ml}$

Concentrations for black pepper and clove: $0.1,0.2,0.4,0.8,1.6 \mathrm{mg} / \mathrm{ml}$

For better results the procedure was repeated for black pepper and clove, this time at concentrations 1, 2, 4, 6, $8 \mathrm{mg} / \mathrm{ml}$.

\section{Disk diffusion method}

Prepare 12 ( 6 plates with three divisions and 6 plates with two divisions) agar plates and inoculate 6 with E. coli and 6 with S. aureus, with the help of spreader, as shown in Fig. 2. Disks with concentration $100 \%, 75 \%$ and $50 \%$ of each ethanol extract are placed in respective plates. ${ }^{10}$

\section{Inoculation:}

Inoculum was prepared by adding 500 microlitres of strain to $50 \mathrm{ml} \mathrm{LB}$ broth. Inoculated broth was incubated at $37^{\circ} \mathrm{C}$ for $24 \mathrm{hr}$.

Each petri plate was divided into half, with a marker and inoculated with 200 microlitres of Staphylococcus aureus on one half and 200 microlitres E. coli on the other half with help of micropipette.

These plates were then left in the incubator at 37 degree Celsius for 24 hrs.

\section{Results}

The inhibitory effect increases with increasing concentration of extracts. Different spices show different effects in ethanol and water.

\section{A- MIC determination}

Minimum inhibitory concentrations (MICs) is the lowest concentration of extract which prevents the visible growth of bacteria. MIC (in mg/ml) of all the extracts are recorded in Table 2 and the results are depicted in Fig. 3. Clove extracts, both ethanolic and aqueous, are most effective against both bacteria. 
Table 2

Minimum inhibitory concentration (in $\mathrm{mg} / \mathrm{ml}$ ) of spices

extracts, in ethanol and water, against Esterichia

coliand Staphylococcus aureus.

\begin{tabular}{|c|c|c|}
\hline PLANT EXTRACT & MIC (in $\mathrm{mg} / \mathrm{ml}$ ) & \\
\hline AQUEOUS EXTRACT & E. coli & S. aureus \\
\hline 1- BLACK PEPPER & 1 & Less than 0.5 \\
\hline 2- CAROM & More than 8 & More than 8 \\
\hline 3- CINNAMON & More than 8 & More than 8 \\
\hline 4- CLOVE & Less than 0.5 & Less than 0.5 \\
\hline 5- CUMIN & More than 8 & More than 8 \\
\hline \multicolumn{3}{|l|}{ ETHANOL EXTRACT } \\
\hline 1- BLACK PEPPER & More than 8 & More than 8 \\
\hline 2- CINNAMON & More than 8 & 8 \\
\hline 3- CLOVE & 6 & 6 \\
\hline 4- CUMIN & More than 8 & 8 \\
\hline
\end{tabular}

\section{B-Zone of inhibition}

The zone of inhibition is the zone encircling the disk, in which no growth of bacteria is seen. It is simply measured with a metric scale. The zone of inhibition for all the extracts are recorded in Table 3. However, Fig. 4 shows the picture of the formation of zone of inhibitions for the ethanolic extracts. Clove is seen to be more effective for E. coli than Staphylococcus aureus while cumin, carom, cinnamon and black pepper are more effective for Staphylococcus aureus than E. coli. For clove, maximum inhibition was seen at $50 \%$ concentration. Cinnamon and cumin are not much effective for $E$. coli. 
the diameter of zone of inhibition (in $\mathrm{mm}$ ) for the ethanolic extracts of spices, at the different concentrations.

\begin{tabular}{|c|c|c|c|}
\hline \multirow{2}{*}{$\begin{array}{l}\text { NAME OF THE } \\
\text { SPICES } \\
\text { (its } \\
\text { concentration) }\end{array}$} & \multicolumn{2}{|c|}{$\begin{array}{l}\text { ZONE OF } \\
\text { INHIBITION } \\
\text { (in } \mathrm{mm} \text { ) }\end{array}$} & \multirow[t]{2}{*}{ DISCUSSION } \\
\hline & $\begin{array}{l}\text { E. } \\
\text { coli }\end{array}$ & $\begin{array}{l}\text { S. } \\
\text { aureus }\end{array}$ & \\
\hline \multicolumn{3}{|l|}{ Clove } & \multirow{4}{*}{$\begin{array}{l}\text { For } E \text {. coli, Zone of inhibition decreases as concentration increases while for } S \text {. aureus, zone of inhibition is almost } \\
\text { same } \\
\text { for all theconcentrations }\end{array}$} \\
\hline $1-100 \%$ & $\begin{array}{l}20- \\
21\end{array}$ & $14-16$ & \\
\hline $2-75 \%$ & $\begin{array}{l}16- \\
17\end{array}$ & 14 & \\
\hline $3-50 \%$ & $\begin{array}{l}15- \\
17\end{array}$ & $13-15$ & \\
\hline Cumin & & & \multirow{4}{*}{$\begin{array}{l}\text { For } E \text {. coli, no effect is seen and for } S \text {. aureus zone of inhibition is almost same } \\
\text { for all the concentrations }\end{array}$} \\
\hline $1-100 \%$ & 5 & 11 & \\
\hline $2-75 \%$ & 5 & 12 & \\
\hline $3-50 \%$ & 5 & 12 & \\
\hline \multicolumn{3}{|l|}{ Carom } & \multirow{4}{*}{$\begin{array}{l}\text { For } E \text {. coli, zone of inhibition is almost } \\
\text { same for all the concentrations and for } S \text {. aureus, zone of inhibition increases with increase in concentration. }\end{array}$} \\
\hline $1-100 \%$ & $\begin{array}{l}12- \\
15\end{array}$ & $11-14$ & \\
\hline $2-75 \%$ & 12 & $11-13$ & \\
\hline 3- $50 \%$ & 12 & $17-19$ & \\
\hline \multicolumn{3}{|l|}{ Cinnamon } & \multirow[t]{4}{*}{ For $E$. coli, no effect is seen while for $S$. aureus, zone of inhibition increases with increase in concentration. } \\
\hline $1-100 \%$ & 5 & 6 & \\
\hline $2-75 \%$ & 5 & 13 & \\
\hline 3- $50 \%$ & 5 & $14-15$ & \\
\hline \multicolumn{3}{|l|}{ Blackpepper } & \multirow{4}{*}{$\begin{array}{l}\text { For } E \text {. coli, zone of inhibition decreases with increase in concentration and for } S \text {. aureus zone of inhibition increases } \\
\text { with increase in concentration. }\end{array}$} \\
\hline $1-100 \%$ & 16 & $12-14$ & \\
\hline $2-75 \%$ & $\begin{array}{l}15- \\
18\end{array}$ & $14-15$ & \\
\hline 3- $50 \%$ & 6 & $17-20$ & \\
\hline
\end{tabular}

\section{Conclusion And Discussion}

Medicinal plants are currently in considerable significance view due to their special attributes as a large source of therapeutic phytochemicals that may lead to the development of novel drugs. Most of the phytochemicals from plant sources such as phenolics and flavonoids have been reported, to have positive impact on health and cancer prevention and are also associated with their antioxidant activities that play a role in the prevention of the development of age-related disease, particularly cause by oxidative stress. ${ }^{11}$

Major antimicrobial components in clove, cumin and cinnamon have been reported to be eugenol, cuminic aldehyde and cinnamaldehyde, respectively. ${ }^{12}$ Eugenol has been reported to inhibit the growth of $E$. coli. Cinnamaldehyde has been reported to inhibit the growth of $S$. aureus, $E$. coli, and Salmonella typhimurium. The alkaloids like piperine, piperidine and resins are responsible for the antibacterial activity of black pepper. While the antimicrobial potential of carom seeds lies in its oil which mostly constitutes thymol.

In this study, the antimicrobial activity of spices, with the aqueous and ethanolic extracts of clove, cumin, carom, cinnamon and black pepper was evaluated with gram-negative bacteria, E. coli and gram-positive bacteria, S. aureus. They were tested with both agar dilution and disk diffusion method to determine the minimum inhibitory concentrations and zone of inhibition of the extracts at different concentrations. The hypothesis, that spices are quite promising antimicrobial agents has proved correct, while Clove and black pepper have showed the great antimicrobial activities against the test organisms. Clove showed the biggest zone of inhibition which is $21 \mathrm{~mm}$. It was also noted that most of the spice extracts were effective against gram-positive bacteria i.e. Staphylococcus aureus that the gram-negative bacteria.

\section{Declarations}




\section{ACKNOWLEDGEMENTS}

We express our sincere gratitude to the Department of Biochemistry of Shaheed Rajguru college of Applied Sciences for Women, Delhi University, India, for providing us with the material, apparatus, instruments and laboratory space to conduct our research.

\section{FUNDING}

This work was supported by the Department of Biochemistry of Shaheed Rajguru college of Applied Sciences for Women, Delhi University.

\section{COMPETING INTEREST}

None of the information to be stated (no funding issues or any conflicts of interest).

\section{AVAILABILITY OF DATA AND MATERIALS}

All data generated or analysed during this study are included in this published article [and its supplementary information files].

\section{AUTHORS' CONTRIBUTIONS}

Current study was done under the mentorship and keen guidance of AG. The research work, finding and initial analysis of the results was done by KG, all the findings were finalized by AG.

\section{CORRESPONDING AUTHOR'S INFORMATION}

The corresponding author of this research article is pursuing her Bachelor's degree in Biotechnology and conducted this research as a part of an internship at Shaheed Rajguru College. Due to the constraints of time, this is a preliminary study. Although further advancements and enhancements are currently under the process.

\section{References}

1. Arora, D. S., \& Kaur, G. J. (2007). Antibacterial activity of some Indian medicinal plants. Journal of natural medicines, 61(3), $313-317$. https://link.springer.com/article/10.1007/s11418-007-0137-8

2. Nanasombat, S., \& Lohasupthawee, P. (2005). Antibacterial activity of crude ethanolic extracts and essential oils of spices against Salmonellae and other enterobacteria. CURRENT APPLIED SCIENCE AND TECHNOLOGY, 5(3), 527-538. https://www.tci-thaijo.org/index.php/cast/article/view/14554

3. Cowan, M. M. (1999). Plant products as antimicrobial agents. Clinical microbiology reviews, 12(4), 564582.https://www.ncbi.nlm.nih.gov/pmc/articles/PMC88925/

4. Khameneh, B., Iranshahy, M., Soheili, V., \& Bazzaz, B. S. F. (2019). Review on plant antimicrobials: A mechanistic viewpoint. Antimicrobial Resistance \& Infection Control, 8(1), 118.https://aricjournal.biomedcentral.com/articles/10.1186/s13756-019-0559-6

5. Sethi, S., Dutta, A., Gupta, B. L., \& Gupta, S. (2013). Antimicrobial activity of spices against isolated food borne pathogens. International Journal of Pharmacy and Pharmaceutical Sciences, 5(1), 260-262. https://pdfs.semanticscholar.org/a81b/7cd91d960c4e136f66a7ee4f46b4a3f48b0b.pdf

6. Mahfuzul Hoque, M. L. Bari, Vijay K. Juneja, \& S. Kawamoto (2008). Antimicrobial Activity of Cloves and Cinnamon Extracts against Food Borne Pathogens and Spoilage bacteria, and Inactivation of Listeria monocytogenes in Ground Chicken meat with their Essential oils. Food Res. Inst, 72 , 9-21. https://www.academia.edu/download/34818249/sh72p009.pdf.

7. Pattaratanawadee, E., Rachtanapun, C., Wanchaitanawong, P., \& Mahakarnchanakul, W. (2006). Antimicrobial activity of spice extracts against pathogenic and spoilage microorganisms. Kasetsart J Nat Sci, 40, 159-165.

https://www.researchgate.net/profile/Chitsiri_Rachtanapun2/publication/267549234_Antimicrobial_Activity_of_Spice_Extracts_against_Pathogenic_and_. Activity-of-Spice-Extracts-against-Pathogenic-and-Spoilage-Microorganisms.pd

8. Azwanida NN (2015) A Review on the Extraction Methods Use in Medicinal Plants, Principle, Strength and Limitation. Med Aromatic Plants 4: 196. doi:10.4172/2167-0412.1000196. http://dx.doi.org/10.4172/2167-0412.1000196

9. Amenu, D. (2014). Antimicrobial activity of medicinal plant extracts and their synergistic effect on some selected pathogens. American Journal of Ethnomedicine, 1(1), 18-29.https://www.academia.edu/download/35766861/PA-800113-_3_.pdf

10. Balouiri, M., Sadiki, M., \& Ibnsouda, S. K. (2016). Methods for in vitro evaluating antimicrobial activity: A review. Journal of pharmaceutical analysis, 6(2), 71-79. https://www.sciencedirect.com/science/article/pii/S2095177915300150

11. Venugopal, R., \& Liu, R. H. (2012). Phytochemicals in diets for breast cancer prevention: The importance of resveratrol and ursolic acid. Food Science and Human Wellness, 1(1), 1-13.https://www.sciencedirect.com/science/article/pii/S2213453012000079

12. Naveed, R., Hussain, I., Tawab, A., Tariq, M., Rahman, M., Hameed, S., ... \& Iqbal, M. (2013). Antimicrobial activity of the bioactive components of essential oils from Pakistani spices against Salmonella and other multi-drug resistant bacteria. BMC complementary and alternative medicine, 13(1), 265.https://link.springer.com/article/10.1186/1472-6882-13-265

\section{Figures}




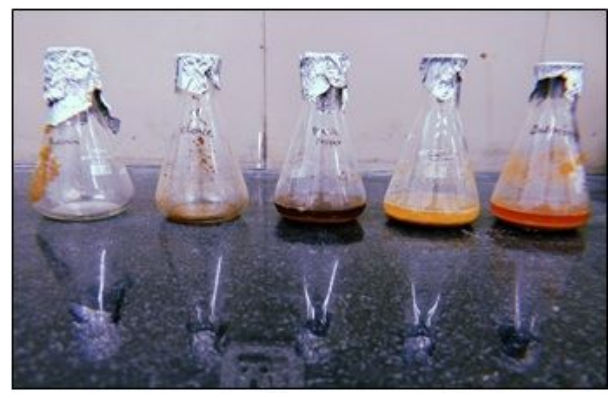

Figure 1

mixture of solvent and solute (spice sample)

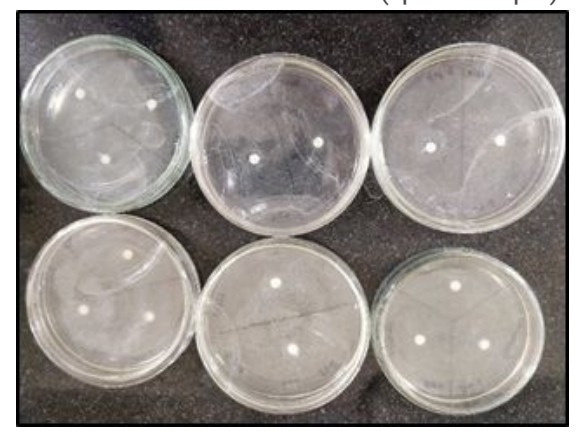

Figure 2

Disks places on agar places inoculated with E. Coli.

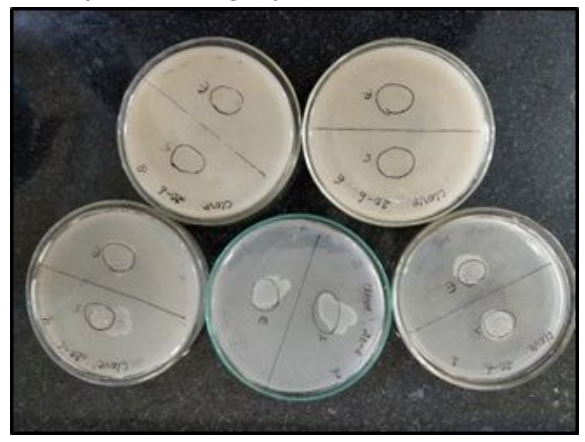

\section{Figure 3}

The results for the clove extracts, for MIC determination.
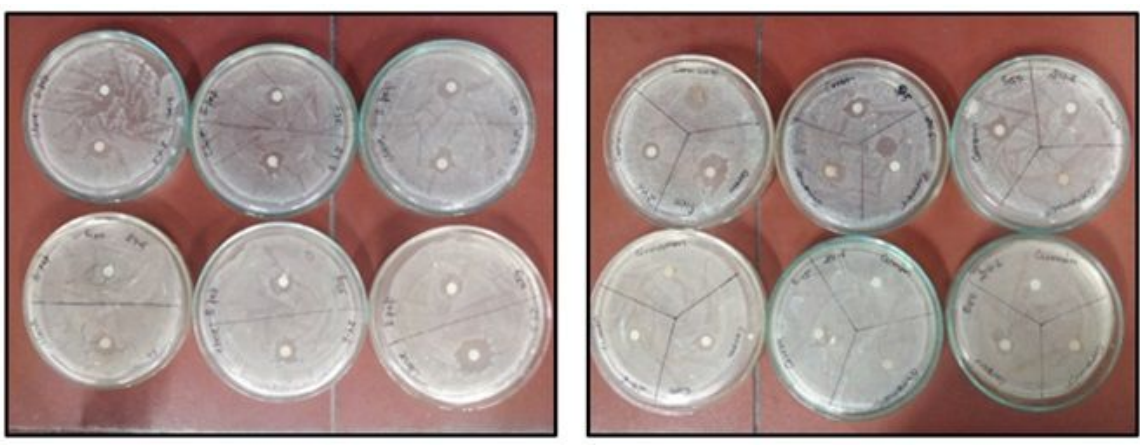

Figure 4

the results to check the zone of inhibition of the ethanolic extracts of spices.

\section{Supplementary Files}

This is a list of supplementary files associated with this preprint. Click to download. 
- Supplementarymaterial.pdf.pdf

Page $8 / 8$ 